\title{
Corrosion of Magnesium in Multimaterial System
}

\author{
VINEET V. JOSHI ${ }^{1,3}$ and SEAN AGNEW ${ }^{2,4}$ \\ 1.-Pacific Northwest National Laboratory, Richland, WA 99352, USA. 2.-Department of Mat- \\ erials Science and Engineering, University of Virginia, Charlottesville, VA, USA. 3.-e-mail: \\ vineet.joshi@pnl.gov. 4.—e-mail: agnew@virginia.edu
}

The TMS Magnesium Committee has been actively involved in presenting cutting-edge research and development and the latest trends related to magnesium and its alloys to industry and academia. Topics including magnesium alloy development, applications, mechanism of deformation and corrosion, thermomechanical processing, modeling, and so on have been captured year after year through the Magnesium Technology symposium and conference proceedings at TMS and through special issues in JOM. Every year, based on the unanimous endorsement from the industry and academia, a topic is selected to address the latest developments within this subject in JOM. In continuation with last year's topic on advances and achievements in in-situ analysis of corrosions and structure-property relationship in $\mathrm{Mg}$ alloys,${ }^{1}$ this year's topic focuses on the corrosion of magnesium in multimaterial systems. Magnesium, the lightest of all the structural materials, has garnered a lot of interest in the transportation, electronics packaging, and industries alike and is more commonly being incorporated in multimaterial design concepts. $^{2-4}$ Nevertheless, the application of the same is limited because of its highly corrosive nature, and understanding and mitigating the corrosion of magnesium has been a major research challenge.

The research community has made significant advances in understanding the mechanism of corrosion, more specifically, looking at macro and micro galvanic corrosion, the evolution of hydrogen, and coatings and film formation on magnesium alloys. A lot of attention has also been focused on looking at the interfaces when it comes to multimaterial systems using a new suite of advanced characterization techniques, setting up novel electrochemical cells and by use of multiphysics models. ${ }^{5-9}$ Significant collaborative efforts between nations are also underway to address this issue. ${ }^{10}$ The three articles

Vineet V. Joshi and Sean Agnew are the JOM advisors for the Magnesium Committee of the TMS Light Metals Division, and guest editors for the topic Corrosion of Magnesium in Multimaterial Systems in this issue. in this special topic address the various aspects associated with understanding the mechanism of corrosion in magnesium-based alloys in multimaterial systems.

In the first paper titled "Evolution of the Corrosion Morphology on AZ31B Tracked Electrochemically and by In Situ Microscopy in ChlorideContaining Media," M.A. Melia et al. describes in real time using an in situ optical technique the propagation of the corrosion filaments on the AZ31 alloy magnesium surface. The reader is highly advised to see the supplemental videos that describe the details of corrosion propagation in the article as a function of the surface potential.

In the second article by B.G. Bazehhour et al. titled "Role of Static and Cyclic Deformation on the Corrosion behavior of a Magnesium-Steel Structural Joint," the influence of monotonic and cyclic deformation on the corrosion behavior of a galvanic joint formed between AE44 magnesium alloy and mild steel is examined. The authors of this work used multiphysics modeling to identify and describe the detrimental physical phenomenon that undermines the structural integrity of the joints under various loading scenarios.

The third article by J.R. Kish et al. is titled "Corrosion Performance of Friction Stir Linear Lap Welded AM60B Joints." This article is a part of the large multinational efforts related to the $\mathrm{Mg}$ alloyintensive, automotive, front-end research and development project. A scanning vibrating electrode technique (SVET) was used to determine the galvanic activity across the joint. This work is particularly interesting as the authors try to understand the mechanism of corrosion caused by the difference in microstructures resulting from the joining process.

The articles are published under the topic "Corrosion of Magnesium in Multimaterial Systems" in the November 2017 issue (vol. 69, no. 11) of JOM and can be accessed via the $J O M$ page at http://link. springer.com/journal/11837/69/11/page/1. 
- "Evolution of the Corrosion Morphology on AZ31B Tracked Electrochemically and by In Situ Microscopy in Chloride-Containing Media" by M.A. Melia, T.W. Cain, B.F. Briglia, J.R. Scully, and J.M. Fitz-Gerald

- "Role of Static and Cyclic Deformation on the Corrosion behavior of a Magnesium-Steel Structural Joint" by B. Gholami Bazehhour, I. Adlakha, and K.N. Solanki

- "Corrosion Performance of Friction Stir Linear Lap Welded AM60B Joints" by J.R. Kish, N. Birbilis, E.M. McNally, C.F. Glover, X. Zhang, J.R. McDermid, and G. Williams.

\section{REFERENCES}

1. D. Orlov and V. Joshi, JOM 68, 3040 (2016).

2. T. Skszek, Demonstration Project for Multi-Material Lightweight Prototype Vehicle as Part of the Clean Energy Dialogue with Canada-Vehma International of America, Inc. and Ford Motor Company, FY2014 Annual Progress Report-Lightweight Materials R\&D, pp. 238-262. http://
energy.gov/sites/prod/files/2015/07/f24/DOE\%20VTO\%2020 14\%20Materials\%20Annual\%20report.pdf.

3. T. Skszek, J. Conklin, D. Wagner, and M. Zaluzec, MultiMaterials Lightweight Vehicles, U.S. DOE 2015 Annual Merit Review Presentation (2015). http://energy.gov/sites/ $\mathrm{prod} /$ files/2015/06/f24//m072_skszek_2015_o.pdf.

4. A.A. Luo, JOM 54, 42 (2002).

5. W.H. Sillekens, D. Casari, W.U. Mirihanage, S. Terzi, R.H. Mathiesen, L. Salvo, R. Daudin, P. Lhuissier, E. Guo, and P.D. Lee, JOM 68, 3042 (2016).

6. D. Tolnai, R.H. Buzolin, F. D'Elia, T. Subroto, S. Gavras, A. Stark, N. Schell, K.U. Kainer, and N. Hort, JOM 68, 3051 (2016).

7. A. Vinogradov and K. Máthis, JOM 68, 3057 (2016).

8. A. Milenin, P. Kustra, D. Byrska-Wójcik, O. Grydin, M. Schaper, T. Mentlein, G. Gerstein, and F. Nürnberger, JOM 68, 3063 (2016).

9. A.R. Headand and J. Schnadt, JOM 68, 3070 (2016).

10. J.H. Forsmark, M. Li, D.A. Wagner, J. Zindel, A.A. Luo, J.F. Quinn, R. Verma, Y.M. Wang, S.D. Logan, and R.C. McCune, Magnesium Technology 2014, ed. M. Alderman, M.V. Manuel, N. Hort, and N.R. Neelameggham (Warrendale, PA: The Minerals, Metals \& Materials Society; Hoboken, NJ: John Wiley \& Sons, 2014), pp. 517-524. 